\title{
INFORMATION POLICY IN THE PARISHES OF THE ROMAN CATHOLIC CHURCH IN THE DIOCESE OF RZESZÓW - A COMPARATIVE ANALYSIS OF RESEARCH RESULTS
}

\begin{abstract}
The paper contains a comparison and analysis of the results of the authors' research on information policy conducted by priests in the parishes of the Roman Catholic Church in the Diocese of Rzeszów. The research was conducted as part of two similar research projects. The first one was implemented at the turn of 2012 and 2013. The second study, based on the same assumptions, was repeated in 2018. The research was carried out using anonymous questionnaires. The aim of the study was to analyze the information policy carried out in parishes by priests. The questionnaire contained questions concerning elements of the parish information policy; information policy tools used in parishes; priests' opinions on information policy tools preferred by parishioners; information policy tools that priests consider to be the most effective; information policy tools that priests would like to use, but this is impossible; barriers in using information policy tools in parishes.
\end{abstract}

Keywords: Roman Catholic church, Rzeszów diocese, information policy, communication.

\section{INTRODUCTION}

The article compares and analyses the results of the author's research on information policy conducted by priests in the Roman Catholic parishes in the Diocese of Rzeszów. These results come from two research projects carried out on the similar basis. The first was implemented at the turn of 2012 and 2013. The second study, based on the same assumptions, was repeated in 2018. The research was based on anonymous questionnaires. The aim of both projects was to analyze the information policy pursued in parishes by priests in the Rzeszów diocese, diagnose the information policy tools used in parishes and identify barriers to the development of communication activities addressed to parishioners. The research conducted in both projects has been the basis for the preparation of three scientific publications so far (Chmielewski, Kuca, 2013; Chmielewski, Kuca, 2014-2015, Kuca, Chmielewski, 2019).

\footnotetext{
1 Paweł Kuca PhD, Department of Political Science, University of Rzeszów, Rzeszów ul. mjr. W. Kopisto 2a, 35-959; e-mail: pawel.kuca@ur.edu.pl. ORCID: 0000-0001-9424-090X (corresponding author).

2 Zbigniew Chmielewski PhD, Institute of Journalism and Social Communication, the University of Wrocław; e-mail: zbigniew@ chmielewskitf.pl. ORCID: 0000-0001-6641-4212.
} 


\section{REQUIREMENTS FOR COMMUNICATION OF CHURCH INSTITUTIONS}

The foundations of the research conducted were the authors' conviction that the Church, like any organization, should pursue an information policy. This task should be carried out by church structures at every organizational, global and local level, including parish level, which are the closest to the faithful. Communication activities conducted in accordance with the principles of professionalism may influence the formation of the relationship of a parish with the faithful, which is in line with the principles applied to other entities or organizations. S. Michałowski drew attention to these aspects, e.g. in relation to local selfgovernment. As he emphasized, authentic local government is impossible without a proper information policy, and many critical opinions towards local government units or mistrust to local government authorities result from lack of information policy or mistakes in its implementation (Michałowski, 2006).

S. Gawroński, using the concept of church marketing, analyzed that it can influence two processes, which concern the Church: an increase in the number of active believers, but also counteracting the processes of weakening of religious commitment in the Poles (Gawroński, 2013). It is also emphasized that changes that take place in the modern world also have an impact on the forms and scope of evangelization activities. They can be conducted not only in the church, but in all places where are people with their problems. Media, for example, could be used for such activities (Drożdż, 2011).

The role of an effective information policy becomes even more important for the representatives of the Church in the face of the expanding technological possibilities of conducting communication activities. The development of online media, social networking sites with principles of professionalism allow communicating effectively with the younger generation, which seems essential for the Church. In order to reach e.g. young people, one should speak their language and be present in the world in which they function. This world becomes increasingly Internet-based Gawroński, 2003). The attention should be paid to the consciousness of ecclesiastical hierarchs about these processes. For example, cardinal Crescenzio Sepe, Archbishop of Naples, pointed out that the Church should be active in the sphere of communication, but also activities in this area, implemented properly, could prevent the Church from many mistakes that occurred (Krzyżak, 2019).

K. Marcyński claims that if the Church wants to be "heard in the social space", it must be present on the informational highway. The Internet is one of its elements, because people are there now (Marcyński, 2011). The aforementioned Cardinal Crescenzio Sepe stated that if Jesus lived in the modern times, he would be present in places such as Facebook (Krzyżak, 2019). This is in line with the view that the presence of priests in social media can also have a pastoral character. If they perceive their activity e.g. on Facebook as a pastoral activity, their friends may have contact with religious content (Laskowska, 2014). From the point of view of the effectiveness of evangelization activities carried out in social networks, an important issue is the appropriate professionalism level (Przybysz, 2013). On the other hand, the condition of professionalism should be applied to all activities carried out as part of communication activities of church structures.

\section{METHODOLOGY OF CONDUCTED RESEARCH}

The research presented in the article was carried out in the Diocese of Rzeszów. It has been functioning since 25 March 1992. It was created from part of Przemyśl diocese, of which 14 deaneries entered the new one and the diocese of Tarnów, of which 5 deaneries 
entered into the new diocese of Rzeszów. At the time of its establishment, the Rzeszów diocese was divided into 201 parishes, 423 diocesan and 68 religious priests worked there, as well as 224 religious nuns (http://www.diecezja.rzeszow.pl/2015/04/podzial-administracyjny-diecezji; http://www.diecezja.rzeszow.pl/2015/05/powstanie-diecezji).

Currently, over 600,000 people live in the diocese. The diocese is administratively divided into 25 deaneries and 244 parishes, it employs 710 diocesan priests (including those who work outside the diocese and retired), and 120 monks and priests, as well as 348 nuns (http://www.diecezja.rzeszow.pl/2015/04/diecezja-podstawowe-informacje). It is worth noting that the Rzeszów Diocese is one of those where there is a high level of religious commitment of the faithful. The research of the Institute of Statistics of the Catholic Church shows that in 2017, 64.1 percent of the congregation participated in the diocese of Rzeszów in the Sunday Holy Mass. This is the second result in Poland, after the Tarnów diocese (ANNUARIUM STATISTICUM ECCLESIAE IN POLONIA).

The research conducted at the turn of 2012 and 2013 and in 2018 was carried out based on similar methodological assumptions. The research was conducted using the method of anonymous questionnaire interviews. The first project lasted from December 2012 to January 2013, while the second project was carried out from June to September 2018. In both cases, the questionnaires were sent via the Diocesan Curia in Rzeszów to all parishes in the diocese (240 in 2012 and 244 in 2018). In 2013, the answers were obtained from 81 parishes (33.7\%), and in 2018 the questionnaires were completed by representatives of 85 parishes, which accounted for 34.8 percent of all parishes in the diocese. In 2018, the majority of questionnaires were sent to the Diocesan Curia. Several letters to the authors of the research, and a dozen questionnaires were also obtained through individual contacts with parishes. In case of both studies, the obtained response rate was considered sufficient to conduct the analysis. However, due to the number of respondents who took part in the study (below 100), the authors based their analysis of the results on numerical indications, not percentages.

The representatives of rural parishes prevailed among the respondents ( 55 subjects in 2012 and 56 in 2018). The remaining priests worked in urban parishes (26 in 2012 and 25 in 2018). Additionally, four priests indicated working in urban-rural parishes in 2018. Analyzing the respondents in terms of their functions in the parish, the majority of them were parish priests (77 in 2012 and 68 in 2018). The vicars also took part in the study - 3 in 2012 and 17 in 2018. During the implementation of the first research in 2012, one of the priests did not indicate the function fulfilled in the parish.

The surveyed priests were in different age groups. The largest group were priests aged 46 to 55 (42 people in 2012 and 33 people in 2018). The second largest age group were priests aged 56-65 (19 examined in 2012 and 28 people in 2018). In a study conducted in 2018,8 priests were in the age group of 36-45 years, in 2012 there were 12 such priests. In the respondents' group in 2018 , there were more young people in the age group $25-35$. There were 12 of them, compared to 1 in 2012. A similar number of priests at the age of 66 or over took part in both projects (three in 2012 and four in 2018).

Both studies were carried out based on the same research questionnaire. There were 9 questions in it, including semi-open and open questions. The first question concerned elements that priests consider to be a part of the parish information policy. The subjects could indicate any number of the 13 tools listed in the cafeteria. Further questions concerned information policy tools that are used in parishes, as well as priests' opinions on information policy tools preferred by parishioners. 
Table 1. Priests participating in the survey broken down by age groups

\begin{tabular}{|c|c|c|}
\hline Participants' age & Study of 2012/2013 & Study of 2018 \\
\hline $25-35$ & 1 & 12 \\
\hline $36-45$ & 12 & 8 \\
\hline $46-55$ & 42 & 33 \\
\hline $56-65$ & 19 & 28 \\
\hline 66 and over & 3 & 4 \\
\hline
\end{tabular}

Source: own research.

The questionnaire also asked the priests which tools of information policy they considered the most effective in relations with the faithful from the point of view of the parish's information policy. The priests participating in the study were also asked to make a subjective assessment of the level of information of the faithful about the parish's activities.

The respondents also indicated the information policy tools they would like to use, but for some reasons it impossible. They also identified barriers to the use such tools. In the open question, priests could also indicate whether they use their own information policy tools other than those listed in the cafeteria in question 1 . The questionnaire asked whether priests are interested in raising competence in communication through personal participation or delegating a person from the parish to workshops in the field of information policy development.

In semi-open questions, the cafeteria contained 13 elements assigned by the authors to the instrumentarium, which can be used in running the information policy of the parish. These were both tools recognized as traditional (parish announcements during Mass, a notice board at the church, parish newsletter, letters to parishioners, media coverage of events, meetings organized in parishes, individual meetings with parishioners) and new tools (website, parish profile on the social network, private profile of the priest on the social network). The cafeteria also includes elements that are not directly related to the information policy tools, but may be used in such activities (sermons, pastoral visit, pilgrimages and trips organized by parishes). The respondents could indicate more than one answer in these questions. Likert scale was used in two questions of the questionnaire from "very often" to "never" and from "definitely yes" to "definitely not". In 2012, Likert scale from "very effective" to "ineffective" was used to assess the efficiency of information policy tools used by parishes in relations with the faithful. The respondents marked a value from 1 to 10 on a linear scale responding to one of the questions - regarding the assessment of the level of information of the faithful.

\section{COMPARISON OF TEST RESULTS}

In the first question, the priests described what elements belong to the components of the parish information policy. The indications from 2012 and 2018 show some differences, but also the persistence of some tendencies at a relatively constant level.

Invariably, the prime communication tool, which was most often indicated by the respondents as a component of the parish information policy, are the parish announcements during the mass. They were indicated both in 2012 and 2018 studies .

Both in 2012 and six years later, parish announcements are ranked as the first in the list of information policy components and are mentioned by almost all respondents. This may 
indicate that the respondents perceived the "information policy" of the parish, primarily in terms of information communication (as opposed to persuasive), providing current information and news, which makes a weekly direct meeting during the Holy Mass, the most important tool for implementation of these goals in the opinion of the respondents.

Support for this argument seems to be another numerical indication of the components of the information policy. In both studies it is "information board at the church". In 2012, it was indicated by 75 respondents, and in 2018 - 81 respondents. The popularity of this tool, unchanged over the last years, also indicates the understanding of information policy in terms of message forwarding, current affairs and announcements. For such purposes, it is used and recognized by parish priests and vicars as an important element of the information policy. This is understandable, because the "information board" is a tool that is easily accessible to anyone visiting the church, it is also easy to use when it comes to the perception of a user.

Comparing the results of the research, the pastoral visit item should be considered as an element of the information policy of the parish. It is high among the responses of the respondents (in 2012 in the third position, and in 2018 in 4). Although it is held once a year, a direct, individual meeting with the faithful at their homes is considered by parish priests and vicars to be an important element of the parish information policy. Pastoral visit is a form of contact with parishioners, which takes place at their homes, is conducted at once (December/January), is implemented systematically every year, in a planned manner and at the same time, includes almost the entire community of the faithful. Due to its form, it is therefore a public relations tool fulfilling the criterion of bidirectional dialogue, allowing not only for the transmission of messages, but also, listening to parishioners, gathering information from them. It enables a real dialogue, and thus interpersonal communication with all its benefits. Visits of the faithful at their homes provide a number of valuable information, starting from the inclination (or lack of thereof) of accepting the priest after the church, the family situation and living conditions of parishioners and their problems. Although it is not clear from the questions in the questionnaire, the above-mentioned features of pastoral visit can be considered as reasons for its persistence on a relatively high position among the elements of the parish information policy, even though it takes place only once a year.

It should be noted that in 2018, the parish website overtook the third position of the pastoral visit as a part of the information policy. This is a manifestation of a wider trend that can be seen in the study. A noticeable increase in the importance of online tools in communicating of the parish is visible over the 6 years that passed from previous research to the current one.

In 2012, 59 out of 81 respondents considered the parish website as an element of information policy, while in 2018 already 72 out of 84 respondents thought so. Similarly, we note an increase in the importance of the "parish profile in social media". In 2012, only 13 out of 81 respondents indicated it as a component of the information policy, and in 2018 there were 32 such indications, which means almost a two and a half times increase. The number of a "priest's profile in social media" is also growing as an element of information policy - from 3 in 2012 to 7 in 2018.

This tendency is followed by the decline in the importance of such traditional forms of information policy as the parish newspaper, pilgrimages and letters to parishioners. As compared to 2012, less respondents now indicate them as elements of information policy. The apparent dichotomy that we observe in case of the parish newspaper should be explained 
by the fact that generally, the number of parishes in which this tool is used is decreasing. However, as the answers to further questions show, its role as an instrument of information policy is important in these parishes where it is still being published. Parish priests consider it important, but not everyone can afford it.

In 2018, a smaller number of the respondents included the "sermon" in the information policy of the parish, which seems not to be due to the decrease in the importance of this form in communicating with the faithful, but rather more frequently interpreting the separation of liturgical elements from strictly informational activities.

Table 2 presents detailed data on the components of the parish information policy in the studies conducted in 2012 and 2018.

Table 2. Components of the parish information policy according to the respondents in 2012/2013 and in 2018

\begin{tabular}{|c|c|c|c|}
\hline \multirow{2}{*}{ Lp. } & Components of the parish information policy & \multicolumn{2}{|c|}{ Number of answers } \\
\cline { 3 - 4 } & $\mathbf{2 0 1 2 / 2 0 1 3}$ & $\mathbf{2 0 1 8}$ \\
$\mathbf{( N = 8 1 )}$ & $\mathbf{N}=\mathbf{8 5})$ \\
\hline 1. & Parish announcements during the Holy Mass & 80 & 84 \\
\hline 2. & Information board at the church & 75 & 81 \\
\hline 3. & Pastoral visit & 64 & 69 \\
\hline 4. & Website of the parish & 59 & 72 \\
\hline 5. & Parish newspaper & 46 & 39 \\
\hline 6. & Meetings organized by the parish & 44 & 42 \\
\hline 7. & Individual meetings with parishioners & 41 & 40 \\
\hline 8. & Sermons & 37 & 27 \\
\hline 9. & Pilgrimages and trips organized by the parish & 37 & 28 \\
\hline 10. & Informing the media about events in the parish & 36 & 28 \\
\hline 11. & Letters to parishioners & 17 & 12 \\
\hline 12. & Profile of the parish on the social network & 13 & 32 \\
\hline 13. & Private profile of a priest on a social network & 4 & 7 \\
\hline
\end{tabular}

Source: own research.

Opinions on the frequency of using particular communication tools in the information policy of the parish shed light about their importance. The information board and parish announcements are among traditional forms of communication used more often than in 2012. In 2018 both forms were indicated by a larger number of respondents as used "very often" and more "often" than it was six years before. This increase is not at the expense of other tools, but results from the general trend of increased demand for information and greater expectations in this regard from the faithful. Communication in all types of organizations is increasingly becoming a standard and the pressure in this regard concerns also the parish.

Increasing trend in the use of online media is clearly visible. 62 respondents mentioned Parish website as "often" and "very often used", while in 2012 it was recognized by 39 respondents. The trend to have the parish's profile in social media is even more apparent. The increase in the number of respondents declaring the use of this form "very often" or "often" rocketed from 4 to 15 over the past 6 years. Nevertheless, it should be noted that 
despite the increase in use of this information policy tool over the past years, social media still have large reserves in the information policy pursued by the respondents.

At the same time, the frequency of using some traditional tools decreased. This is less noticeable in relation to e.g. letters to parishioners or pilgrimages, which were less frequent in 2012 than in 2018. The tools such as parish newspapers and informing local media about events in the parish were clearly less frequently used in the information policy of the parish in 2018.

Table 3 presents data regarding the frequency of using individual methods and tools of information policy in the parishes of the Diocese of Rzeszów.

Table 3. Frequency of using particular methods and tools of the parish information policy in $2012 / 2013$ and in 2018

\begin{tabular}{|c|c|c|c|c|c|c|c|c|c|c|c|c|}
\hline \multirow{2}{*}{$\begin{array}{c}\text { Information } \\
\text { policy tool }\end{array}$} & \multicolumn{2}{|c|}{ Very often } & \multicolumn{2}{|c|}{ Often } & \multicolumn{2}{|c|}{ Rarely } & \multicolumn{2}{|c|}{ Very rarely } & \multicolumn{2}{|c|}{ Never } & \multicolumn{2}{|c|}{$\begin{array}{c}\text { Numer of } \\
\text { respondents }\end{array}$} \\
\hline & 2012/2013 & 2018 & $2012 / 2013$ & 2018 & $2012 / 2013$ & 2018 & $2012 / 2013$ & 2018 & $2012 / 2013$ & 2018 & $2012 / 2013$ & 2018 \\
\hline $\begin{array}{l}\text { Parish } \\
\text { announcements } \\
\text { during the mass }\end{array}$ & 66 & 68 & 7 & 13 & 4 & 1 & 0 & 0 & 0 & 0 & $\mathrm{~N}=77$ & $\mathrm{~N}=82$ \\
\hline $\begin{array}{l}\text { Information } \\
\text { board at the } \\
\text { church }\end{array}$ & 51 & 57 & 15 & 22 & 2 & 0 & 0 & 1 & 1 & 0 & $\mathrm{~N}=69$ & $\mathrm{~N}=80$ \\
\hline Pastoral visit & 24 & 22 & 22 & 27 & 10 & 10 & 4 & 5 & 0 & 0 & $\mathrm{~N}=60$ & $\mathrm{~N}=64$ \\
\hline Parish website & 33 & 47 & 6 & 15 & 2 & 0 & 2 & 0 & 4 & 1 & $\mathrm{~N}=47$ & $\mathrm{~N}=63$ \\
\hline Sermon & 22 & 23 & 15 & 11 & 6 & 5 & 6 & 6 & 1 & 2 & $\mathrm{~N}=50$ & $\mathrm{~N}=47$ \\
\hline $\begin{array}{l}\text { Meetings } \\
\text { organized } \\
\text { by the parish }\end{array}$ & 6 & 5 & 22 & 19 & 11 & 17 & 3 & 7 & 0 & 1 & $\mathrm{~N}=42$ & $\mathrm{~N}=49$ \\
\hline $\begin{array}{l}\text { Individual } \\
\text { meetings with } \\
\text { parishioners }\end{array}$ & 9 & 7 & 22 & 26 & 10 & 8 & 3 & 6 & 0 & 1 & $\mathrm{~N}=44$ & $\mathrm{~N}=48$ \\
\hline Parish leaflet & 11 & 14 & 11 & 3 & 4 & 4 & 4 & 3 & 7 & 12 & $\mathrm{~N}=37$ & $\mathrm{~N}=36$ \\
\hline $\begin{array}{l}\text { Pilgrimages and } \\
\text { trips organized } \\
\text { by the parish }\end{array}$ & 6 & 4 & 14 & 13 & 23 & 23 & 6 & 5 & 0 & 1 & $\mathrm{~N}=49$ & $\mathrm{~N}=46$ \\
\hline $\begin{array}{l}\text { Informing the } \\
\text { media about the } \\
\text { events of the } \\
\text { parish }\end{array}$ & 5 & 1 & 5 & 5 & 13 & 14 & 12 & 14 & 3 & 2 & $\mathrm{~N}=38$ & $\mathrm{~N}=36$ \\
\hline $\begin{array}{l}\text { Profile on a so- } \\
\text { cial network }\end{array}$ & 4 & 11 & 0 & 4 & 0 & 2 & 0 & 0 & 16 & 10 & $\mathrm{~N}=20$ & $\mathrm{~N}=27$ \\
\hline $\begin{array}{l}\text { Private profile } \\
\text { of a priest on } \\
\text { a social network }\end{array}$ & 1 & 2 & 1 & 1 & 1 & 3 & 1 & 5 & 12 & 8 & $\mathrm{~N}=16$ & $\mathrm{~N}=19$ \\
\hline $\begin{array}{l}\text { Letters to } \\
\text { parishioners }\end{array}$ & 0 & 0 & 1 & 0 & 6 & 3 & 9 & 3 & 11 & 15 & $\mathrm{~N}=27$ & $\mathrm{~N}=21$ \\
\hline
\end{tabular}

Source: own research.

In both surveys, the respondents were asked to evaluate the effectiveness of information policy tools used in parishes. It is interesting to compare whether the assessment of the effectiveness of these tools by the priests and vicars using them changes and in what way. Research shows that over the last six years, the catalogue of tools that priests assessed as the most effective in information policy has not changed. It should not come as a surprise that both in 2012 and 2018, announcements during the Holy Mass and information board at 
the church were considered the most effective. Priests invariably believe that parishioners obtain information about the life of the parish most effectively from these sources. The parish website was in third place. It is worth noting that in 2018 we can see a numerical increase in the indications on the parish website as the most effective tool in communication activities (51 indications). This should be considered as confirmation of the growing importance of online tools in the parish instrumentation in the Rzeszów diocese. A pastoral visit is in the forefront of effective tool in both studies. It is worth noting, however, that according to the respondents, social media have distant positions in the ranking of effectiveness of information policy tools. Parish profiles in social media was indicated as an effective tool in 2018 by more respondents than in 2012, but still only a small group of priests considers this tool to be effective. This applies even more to the private profiles of priests in social media. Thus, it can be seen that modern forms are successively permeating the communication instrumentation in the parishes of the Rzeszów diocese, but this process is slower than in other organizations. While the "older" internet tools such as the website are now widely used and recognized as effective, tools associated with social media, despite lightly growing belief in their effectiveness, have not yet entered the parish communication workshop in the diocese of Rzeszów area.

Table 4 and 5 presents data regarding the assessment of the effectiveness of information policy tools used in parishes of the Rzeszów diocese.

Table 4. Assessment of the effectiveness of parish information policy tools according to priests in 2012/2013

\begin{tabular}{|l|c|c|c|c|c|}
\hline \multicolumn{1}{|c|}{$\begin{array}{c}\text { Information } \\
\text { policy tool }\end{array}$} & $\begin{array}{c}\text { Very } \\
\text { effective }\end{array}$ & $\begin{array}{c}\text { Moderately } \\
\text { effective }\end{array}$ & $\begin{array}{c}\text { Little } \\
\text { effective }\end{array}$ & Ineffective & $\begin{array}{c}\text { Number } \\
\text { of respondents }\end{array}$ \\
\hline $\begin{array}{l}\text { Parish announcements } \\
\text { during the mass }\end{array}$ & 59 & 10 & 0 & 0 & $\mathrm{~N}=69$ \\
\hline $\begin{array}{l}\text { Information board at the } \\
\text { church }\end{array}$ & 23 & 21 & 5 & 0 & $\mathrm{~N}=49$ \\
\hline Pastoral visit & 21 & 10 & 1 & 0 & $\mathrm{~N}=32$ \\
\hline Parish website & 29 & 10 & 2 & 0 & $\mathrm{~N}=41$ \\
\hline Sermon & 17 & 9 & 3 & 1 & $\mathrm{~N}=30$ \\
\hline $\begin{array}{l}\text { Meetings organized } \\
\text { by the parish }\end{array}$ & 13 & 10 & 0 & 0 & $\mathrm{~N}=23$ \\
\hline $\begin{array}{l}\text { Individual meetings with } \\
\text { parishioners }\end{array}$ & 16 & 5 & 1 & 0 & $\mathrm{~N}=22$ \\
\hline Parish leaflet & 18 & 6 & 2 & 4 & $\mathrm{~N}=30$ \\
\hline $\begin{array}{l}\text { Pilgrimages and trips } \\
\text { organized by the parish }\end{array}$ & 8 & 6 & 3 & 0 & $\mathrm{~N}=17$ \\
\hline $\begin{array}{l}\text { Informing the media } \\
\text { about the events of the } \\
\text { parish }\end{array}$ & 6 & 5 & 6 & 0 & $\mathrm{~N}=17$ \\
\hline $\begin{array}{l}\text { Profile on a social } \\
\text { network }\end{array}$ & 1 & 2 & 1 & 3 & $\mathrm{~N}=7$ \\
\hline $\begin{array}{l}\text { Private profile of } \\
\text { a priest on a social } \\
\text { network }\end{array}$ & 0 & 2 & 1 & 3 & $\mathrm{~N}=6$ \\
\hline Letters to parishioners & 2 & 4 & 3 & 1 & $\mathrm{~N}=10$ \\
\hline
\end{tabular}

Source: own research. 
Table 5. The most effective tools of the information policy of the parish according to priests (2018)

\begin{tabular}{|l|c|}
\hline \multicolumn{1}{|c|}{ Information policy tools } & $\begin{array}{c}\text { The most } \\
\text { effective tool }\end{array}$ \\
\hline Parish announcements during the mass & 80 \\
\hline Information board at the church & 42 \\
\hline Pastoral visit & 32 \\
\hline Parish website & 51 \\
\hline Sermon & 18 \\
\hline Meetings organized by the parish & 6 \\
\hline Individual meetings with parishioners & 10 \\
\hline Parish leaflet & 17 \\
\hline Pilgrimages and trips organized by the parish & 7 \\
\hline Informing the media about the events of the parish & 1 \\
\hline Profile on a social network & 1 \\
\hline Private profile of a priest on a social network & 1 \\
\hline Letters to parishioners & 1 \\
\hline
\end{tabular}

Source: own research.

Another issue raised in the research were the barriers to the use of information policy tools. It was an attempt to answer the question what is preventing the wider use of instruments used to communicate with the faithful, which priests consider to be important and effective. Both in 2012 and in 2018, the respondents indicated four main problems in this respect, although over the years, the importance of particular barriers has changed. In 2012, the most important problems hindering the use of effective communication tools indicated by priests were the lack of financial resources and lack of qualified staff that could use tools in the field of information policy ("definitely" and "rather yes" were mentioned by 33 respondents). As the third barrier, the priests indicated lack of time to use communication tools ("definitely" and "rather yes" this factor was mentioned by 28 respondents), followed by insufficient equipment and technologies ("definitely" and "rather yes" - 26 indications).

In the study carried out in 2018, the same barriers were indicated as the most important, but in a different order. The greatest barrier indicated was the lack of qualified staff (30 "definitely" and "rather yes") as well as lack of time (29 indications "definitely" and "rather yes"). The lack of appropriate equipment and technology was indicated in the third place (27 indications "definitely" and "rather yes"). The lack of money has significantly lost its importance and has ceased to be the main barrier in a more complete use of communication tools ("definitely" and "rather yes" - 21 indications).

The detailed data on the barrier in the application of information policy tools in the parishes of the Diocese of Rzeszów are presented in table 6.

Invariably, both in 2012 and in 2018, parish priests and vicars highly appreciated the level of informing the faithful about the matters of the parish. In their opinion, on a scale of 1 to 10 , the effectiveness of communication can be assessed on average at 8.25 in 2012 and 8.32 in 2018. Such an assessment can be considered highly optimistic (in 2012 as many as 32 out of 76 respondents indicated 9 or 10 points, and in 2018 such a level of information was indicated by 40 out of 84 respondents). The distribution of grades in both studies is 
very similar, and small differences result from the sample size. It would be interesting to examine the opinions of the faithful in terms of feeling the degree of information about the parish matters. Such a comparison would certainly shed new light on the state of dialogue in the parishes of the Rzeszów diocese. The authors do not exclude attempts to undertake such research.

Table 6. Barriers in the use of information policy tools

\begin{tabular}{|c|c|c|c|c|c|c|c|c|c|c|c|c|}
\hline \multirow{2}{*}{$\begin{array}{l}\text { The barrier in } \\
\text { using infor- } \\
\text { mation policy }\end{array}$} & \multicolumn{2}{|c|}{ Definitely yes } & \multicolumn{2}{|c|}{ Rather yes } & \multicolumn{2}{|c|}{ Rather not } & \multicolumn{2}{|c|}{ Definitely not } & \multicolumn{2}{|c|}{ Difficult to say } & \multicolumn{2}{|c|}{$\begin{array}{c}\text { Numer } \\
\text { of indications }\end{array}$} \\
\hline & $\begin{array}{l}2012 / \\
2013\end{array}$ & 2018 & $\begin{array}{l}2012 / \\
2013\end{array}$ & 2018 & $\begin{array}{l}2012 / \\
2013\end{array}$ & 2018 & $\begin{array}{l}2012 / \\
2013\end{array}$ & 2018 & $\begin{array}{l}2012 / \\
2013\end{array}$ & 2018 & $\begin{array}{l}2012 / \\
2013\end{array}$ & 2018 \\
\hline Lack of money & 17 & 13 & 16 & 8 & 7 & 7 & 5 & 5 & 5 & 7 & $\mathrm{~N}=50$ & $\mathrm{~N}=40$ \\
\hline $\begin{array}{l}\text { Lack of quali- } \\
\text { fied staff }\end{array}$ & 13 & 9 & 20 & 21 & 9 & 7 & 1 & 2 & 7 & 4 & $\mathrm{~N}=50$ & $\mathrm{~N}=43$ \\
\hline $\begin{array}{l}\text { Lack of inter- } \\
\text { est / acceptan- } \\
\text { ce on the part } \\
\text { of residents }\end{array}$ & 4 & 3 & 10 & 16 & 8 & 10 & 8 & 3 & 13 & 8 & $\mathrm{~N}=43$ & $\mathrm{~N}=40$ \\
\hline $\begin{array}{l}\text { No time to use } \\
\text { new tools }\end{array}$ & 10 & 14 & 18 & 15 & 7 & 6 & 2 & 3 & 8 & 5 & $\mathrm{~N}=45$ & $\mathrm{~N}=43$ \\
\hline $\begin{array}{l}\text { Misunderstan- } \\
\text { ding on the } \\
\text { part of su- } \\
\text { periors }\end{array}$ & 2 & 1 & 2 & 3 & 5 & 8 & 27 & 17 & 1 & 4 & $\mathrm{~N}=37$ & $\mathrm{~N}=33$ \\
\hline $\begin{array}{l}\text { Media nega- } \\
\text { tivity }\end{array}$ & 7 & 1 & 9 & 6 & 10 & 11 & 10 & 12 & 4 & 4 & $\mathrm{~N}=40$ & $\mathrm{~N}=34$ \\
\hline $\begin{array}{l}\text { Insufficient } \\
\text { equipment and } \\
\text { technology }\end{array}$ & 14 & 15 & 12 & 12 & 7 & 6 & 4 & 2 & 2 & 3 & $\mathrm{~N}=39$ & $\mathrm{~N}=38$ \\
\hline
\end{tabular}

Source: own research.

Table 7 presesnts the opinions of the priests participating in the study regarding the degree of informing the faithful about the parish matters.

Table 7. Priests' assessment about the degree of informing the faithful about their parish affairs (on a scale of 1 to 10 )

\begin{tabular}{|l|c|c|c|c|c|c|c|c|c|c|}
\hline $\begin{array}{l}\text { The year of } \\
\text { research }\end{array}$ & $\mathbf{1}$ & $\mathbf{2}$ & $\mathbf{3}$ & $\mathbf{4}$ & $\mathbf{5}$ & $\mathbf{6}$ & $\mathbf{7}$ & $\mathbf{8}$ & $\mathbf{9}$ & $\mathbf{1 0}$ \\
\hline $\begin{array}{l}\mathbf{2 0 1 2 / 2 0 1 3} \\
\mathbf{N = 7 6}\end{array}$ & 0 & 0 & 0 & 2 & 2 & 5 & 12 & 23 & 16 & 16 \\
\hline $\begin{array}{l}\mathbf{2 0 1 8} \\
\mathbf{N}=\mathbf{8 4}\end{array}$ & 0 & 0 & 0 & 0 & 4 & 3 & 13 & 24 & 22 & 18 \\
\hline
\end{tabular}

Source: own research.

Regardless of the relatively high self-esteem of parish priests and vicars in terms of the effectiveness of communication activities, they appreciate (at least on the declarative level) the importance of workshops in the field of forming information policy for the development of parish communication activities. It can be argued that a large proportion of the respondents feel the need to raise the level of professionalism in the field of communication in the parish.

Half of the respondents, both in 2012 and in 2018, would send a representative of the parish to a workshop on the conduct of information policy. At the same time, in the last six 
years, the number of priests who would like to take part in such training personally increased. While in 2012 such a declaration was made by 15 out of 79 respondents, in 2018 there were already 27 out of 85 .

The respondents also emphasize the importance of the practical aspect of such workshops. A larger number of the respondents mention this when it comes to their participation in training. On the other hand, the clearly smaller number of parish priests and vicars conditions their participation in the workshops on the fact they are free of charge. While in 2012 such condition was imposed by 25 out of 79 respondents answering this question, in 2018 only 17 out of 85 .

It confirms that the importance of financial resources as a barrier to the parish's communication activities has decreased. In 2018 money was not a primary problem for priests in their implementation (see also Table 5), which obviously does not mean that the issue disappeared completely. It can be noticed that the number of people declaring willingness to participate in paid trainings not only did not increase, but decreased relatively, which indicates the lack of a decisive willingness to take paid trainings and workshops. The same number of priests in both studies (17 people) unequivocally declared that they were not interested in information policy workshops regardless of their form, price or other conditions.

The results of the research regarding the interest of priests or a parish representative in workshops on information policy are presented in Table 8.

Table 8. Interest in attending the workshops in shaping the information policy by priests or a representative of the parish

\begin{tabular}{|c|c|c|}
\hline $\begin{array}{l}\text { Interest in attending workshops in the field of developing } \\
\text { information policy }\end{array}$ & $\begin{array}{c}\text { Years: } \\
\text { 2012/2013, } \\
\text { N=79 }\end{array}$ & $\begin{array}{l}\text { Year } \\
2018, \\
N=85\end{array}$ \\
\hline Yes, I would send someone from the parish & 40 & 40 \\
\hline Yes, provided they are carried out in a practical way & 26 & 32 \\
\hline Yes, provided they are for free & 25 & 17 \\
\hline $\begin{array}{l}\text { Yes, provided that trainers are people from media or Catholic organiza- } \\
\text { tions }\end{array}$ & 18 & 16 \\
\hline Yes, I would take part in them myself & 15 & 27 \\
\hline Yes, even if they will be charged & 7 & 6 \\
\hline I would not be interested in such workshops & 17 & 17 \\
\hline
\end{tabular}

Source: own research.

\section{CONCLUSIONS}

By analyzing the results of both studies, several conclusions can be drawn. The most popular tools in the information policy conducted by priests in the Rzeszów diocese include those from the category of traditional tools. Both in the questions concerning the components of the parish information policy, as well as the frequency of using particular communication tools in parishes, the priests most often indicated the announcements during the mass and the information boards at the church.

Comparing the results of research, the role of online media is worth stressing. Research shows that priests are more aware of the importance of communication in the parish website. Comparing the results of research from 2012 and 2018, this tool is more often used and 
described as effective. However, it leaves much to be desired when it comes to the use of social media. It is true that within a few years, the number of priests who use the parish profiles in social media in the information policy has increased, but it is still a relatively small group in comparison to the whole group of respondents.

It should also be noted that the priests participating in the research declare their willingness to develop a professional information policy of the parish at a relatively high level. This is expressed both in the declaration of sending representatives of the parish to the information policy workshops, as well as the increase in the number of priests who would like to participate in such training personally. This is partly consistent with the view expressed by some of the respondents in 2018 that the greatest barrier inusing the information policy tools in the parish is the lack of qualified staff.

Looking at the results of the research, it would also be worth considering two further research projects that would give a broader picture of the subject. On the one hand, in the context of the priests' high self-assessment regarding the effectiveness of the information policy carried out in parishes, it would be advisable to confront these results with the opinions of the parishioners themselves and to get their opinion on the information policy pursued by the priests. The second interesting study would be to compare the results from the Rzeszów diocese with the information policy pursued by priests in another diocese or dioceses in Poland. The focus should be on those in which the Roman Catholic Church does not have such a strong position as in the Rzeszów diocese. Perhaps it would also affect the scope and manner of conducting the information policy of priests with parishes.

\section{REFERENCES}

ANNUARIUM STATISTICUM ECCLESIAE IN POLONIA, http://iskk.pl/images/stories/ Instytut/dokumenty/Annuarium_Statisticum_2019.pdf (Access on the Internet: 18.01.2019).

Marcyński, K. (2011). Church on the information highway [in:] Przybysz, M., Marcyński, K. SAC (ed.), Media i Kościót. Warsaw.

Drożdż, M. (2011). Principles of the Church's presence in the media [in:] Przybysz, M., Marcyński, K. SAC (ed.), Media i Kościót. Warsaw.

Laskowska, M. (2014). New media in pastoral ministry [in:] Przybysz, M., ks. Wielebski, T. (ed.), Media in pastoral care. Warsaw.

Przybysz, M. (2013). Press advocacy in church institutions in Poland in the context of social media. Kielce.

Kuca, P., Chmielewski, Z. (2019). Information policy of the parish in the Rzeszów diocese in 2018 - research results. "Łódź Theological Studies", 1.

Gawroński, S. (2003). Between Modernity and Traditionalism [in:] Chłopecki, J., SiewierskaChmaj, A. (ed.), Wspótczesna Wieża Babel. Rzeszów.

Gawroński, S. (2013). Non-business areas of using marketing communication in Polish conditions. Warsaw.

Michałowski, S. (2006). Information policy in local government and civil society [in:] Michałowski, S., Mich, W. (ed.), Local authorities and the media. Information managementpublic relations - promotion of local government units. Lublin.

Chmielewski Z., Kuca, P. (2013). Information policy of the parish of the Rzeszów diocese research report. "Polityka i Społeczeństwo", 3.

Chmielewski, Z., Kuca, P. (2014-2015). Limitations and barriers in communicating priests with the faithful - case study of the Rzeszów diocese. "Media Culture Society", 9-10. 
http://www.diecezja.rzeszow.pl/2015/04/diecezja-podstawowe-informacje (Access on the Internet: 16.01.2019).

http://www.diecezja.rzeszow.pl/2015/04/podzial-administracyjny-diecezji (Access on the Internet: 16.01.2019).

http://www.diecezja.rzeszow.pl/2015/05/powstanie-diecezji (Access on the Internet: 16.01.2019).

Krzyżak, T. Twitter. Facebook. Amen, [Access: 27.01.2019]. Access on the Internet: https://www.rp.pl/artykul/1013098-Twitter--Facebook--Amen.html.

DOI: 10.7862/rz.2019.mmr.19

The text was submitted to the editorial office: February 2019.

The text was accepted for publication: October 2019. 
